\title{
A DOWNSIDE TO THE BRAIN GAIN STORY
}

\author{
Ilhom Abdulloev ${ }^{1}$, Gil S. Epstein ${ }^{2}$, Ira N. Gang ${ }^{3}$ \\ date of paper receipt: \\ 16.09.2020. \\ Original Article \\ date of sending to review: \\ 18.09.2020. \\ doi: 10.2478/eoik-2020-0017 \\ date of review receipt: \\ 25.09.2020. \\ UDK 314.151.3:316.344.32-054.72

\footnotetext{
${ }^{1}$ Open Society Institute - Assistance Foundation in Tajikistan, Tajikistan, and IZA, Bonn

${ }^{2}$ Bar-Ilan University, Israel, GLO, CReAm, London and IZA, Bonn

${ }^{3}$ Rutgers University, USA, CReAM, London, GLO, IOS Regensburg, IZA, Bonn and RWI, Essen
}

\begin{abstract}
We consider how the possibility of international migration affects an individual's educational choices in their home country. Educational choice dictates skill, and the paper refers to the highly educated, highly skilled as "professionals"; others are "non-professionals." Without the opportunity to emigrate abroad people choose their educational investment (and hence their skill level) as we might expect. To this normal choice the higher status given professionals is also accounted for. Consider now how the opportunity for international migration to a higher paying job affects both professionals and non-professionals. Despite the higher status a professional enjoys, once an individual takes the possibility of migration to a different country into consideration, he may well decide to choose education leading to non-professional employment. A result of this paper is that if there are low chances of obtaining professional jobs in the host country, individuals may well choose an educational track leading to a low occupational profession in order to increase their chances of obtaining a job in the host country after migration. Thus, all home country students may choose the non-professional education track. Those who might have otherwise pursued higher, professional education may forgo that schooling. The theory developed here explains the forsaken schooling phenomenon. This phenomenon shows that low-skilled and skilled home country workers are willing to accept lowskilled positions in host countries. This leads to the forgoing of professional schooling in the home country since it is not optimal for the worker in the home country to choose a high skilled education since, they will be overqualified in the host country. This will have a long run affect. As time goes on, therefore, people who consider migrating abroad will have either lower years of schooling, or generally have not completed professional schools (technical-vocational or tertiary).
\end{abstract}

Keywords: traps, migration, poverty, inequality, education, skill, brain gain, brain drain JEL: O15, P46, F22, I24 


\section{INTRODUCTION}

The existence and persistence of large international wage differentials among countries drives much of international migration. Discussions of emigration on the home country of the migrants centered on the brain drain, stressing the dire direct impacts of skilled/educated emigration on the home country (Bhagwati and Hamada, 1974; Grubel and Scott, 1966). In contrast, remittances were cited as the positive effect of emigration on the home country (Dimova, 2017; Faini, 2003, 2007). Over time, the literature highlighted more and more aspects of the gain to sending countries: mechanisms such as enhanced returned migrants' skills (Co, Gang and Yun, 2000; Dai, Liu, and Xie, 2015) and skill acquisition by those intending to migrate (the demonstration effect as in Beine, Docquier and Rapoport, 2008). Brain gain is now the name given collectively to the positive effects on the sending country of the emigration of the highly educated. We look at the consequences of international emigration on schooling in the emigrant's home country.

From the start of these literatures, a debate ensued over which dominates: what is the net effect of the brain gain versus the brain drain? Faini (2003) weighs the two, arguing that for skilled migration, remittances are reduced and there is a lack of evidence for the demonstration effect which high returns to skilled emigration will lead to more home country schooling. Remittances are the obvious critical element in the brain gain story. The large literature points to the many beneficial uses of remittances, especially for schooling: increase time at school (Dimova, Epstein \& Gang, 2015, Epstein and Kahana, 2008), better school retention (Duryea, Cox \& Ureta, 2003), and generally positive effects on educational attainment (Yang, 2005; Acosta, 2006; Calero, Bedi, \& Sparrow, 2009; Amuedo-Dorantes \& Pozo, 2010; Bredtmann, Martínez Flores, \& Otten, 2019). Additional funds allow migrant families to pay tuition, transportation costs and for other educational necessities.

The literature also hypothesizes that if the benefits of additional schooling outweigh the costs of skilled labor migration, a "beneficial brain drain" via a "demonstration effect" might ensue (Mountford, 1997; Edwards and Ureta, 2003; Stark, Helmenstein, and Prskawetz, 1997, 1998; Stark and Wang, 2002; Piracha, Randazzo and Vadean, 2013; Beine, Docquier and Rapoport, 2001, 2008). In contrast, we know that with emigration come some negatives. Weiss, Sauer and Gotlibovski (2003) and Özden (2006) argue that brain-waste might arise as educated immigrants take on jobs for which they are over-educated. Most relevant to this paper, Stark and Byra (2012) introduce the concept of a "backwards brain drain", arguing that migrant origin countries can suffer from reduced aggregate skill formation, producing unskilled and fewer skilled laborers. The origin country might be stuck in a low-level equilibrium from which escape is difficult where the education level is stable and lower than necessary for generating significant growth. The Stark and Byra (2012) insight is very appealing, focusing on unintended consequences of international emigration.

The brain drain or brain gain debate focusses on skilled migration - the emigration of the highly educated - and its cost to the home country. Most international migration is to host country unskilled jobs, regardless of the migrants' schooling. We model this latter emigration and look at its effect on migrants' home country educational achievement. We start from the assumption that there are large and persistent international wage difference, to the extent that the highly educated in the home country might emigrate to take low skilled but higher paying host country jobs. However, the highly education are (up to a point) resistant to moving even for large wage differences, as they do not want to give up the status they have in their home country.

Status can take on many nuances. Here, we are thinking of occupational status as largely determined by education. To simplify we think of two levels, professional and nonprofessional, 
with professionals enjoying higher status. With status comes prestige, privilege, and a number of non-monetary awards. Furthermore, the ability of professionals to engage in informal activities enables them to earn enough to compensate family expenses without migrating, while nonprofessionals find it less costly to migrate than to be involved in local informal sector (Abdulloev, Gang, \& Landon-Lane, 2012). Nevertheless, at some point, the wage differential overcomes the resistance to losing status, causing dissatisfaction with current occupations (Abdulloev, 2018). A negative demonstration effect ensues where individuals and families may forgo education, opting to migrate abroad to high paying unskilled jobs, especially when those jobs are paying multiples of skilled jobs at home. The market is discouraging people from investing in education (Abdulloev, Epstein \& Gang, 2020). We term this "schooling forsaken". Since skills and education are major drivers of economic growth and development, the migrant sending country might not progress further towards having a knowledge-based advanced economy. This is a downside to the brain gain story.

The next section presents our core theoretical model. In Section 3, we examine emigration options and the choice of profession. Section 4 extends the model by introducing return migration. We have written several papers looking at this phenomenon empirically. In Section 5, we highlight the results from these. Section 6 concludes.

\section{CORE OF THEORETICAL MODEL}

We draw a link between educational choices and migration for a low-wage country demonstrating our thinking that the ability to migrate and obtain high wages would/may decrease the desirability of higher schooling. This then, as almost all of the literature tells us, is detrimental to economic growth and welfare.

We consider a population of workers whose utility is separable and linear in private consumption that is provided by expenditure of a wage, $w$, and in occupational status, $s$,

$$
W(w, s)=w+s
$$

The worker's occupation determines status. To simplify we assume workers are employed either in a professional occupation or in a non-professional occupation. We think of status, s, as partly a shorthand for educational achievement. A non-professional worker will have a status level of $s=0$ while a professional worker will have a status of $s>0$. All workers are risk neutral in income and risk averse to their status.

Workers maximize present discounted utility, with a rate of time preference $r>0$. The model is set in continuous time. The only choice that a worker makes is selection of educational type: one that leads to either a professional occupation or one that leads to a non-professional occupation. We assume that all workers have the same abilities; thus, if an individual chooses to study the professional track the individual will succeed in obtaining a professional job. In the home market a professional worker will earn $w_{p}$ and a non-professional worker will earn $w_{n}, w_{p}>w_{n}$. With probability $q(p)$ a professional worker will migrate and find a job while with probability $q(n)$ a non-professional worker will migrate and find a job.

$V(p)$ and $V(n)$ are the expected lifetime utilities of professional and non-professional workers, respectively (in a similar way to Epstein and Hillman, 2003). $U(p)$ and $U(n)$ are the expected lifetime utilities of professional and non-professional workers, respectively, who have migrated. For a professional worker, 


$$
r V(p)=w_{p}+s+q(p)(U(p)-V(p))
$$

and for a non-professional worker,

$$
r V(n)=w_{n}+q(n)(U(n)-V(n))
$$

From (2) and (3), we have,

$$
V(p)=\frac{w_{p}+s+q(p) U(p)}{r+q(p)} \text { and } V(n)=\frac{w_{n}+q(n) U(n)}{r+q(n)}
$$

The wage at which a worker is indifferent between being a professional or a non-professional will satisfy $V(p)=V(n)$. If $V(p)<V(n)$, the individual becomes a non-professional worker while if $V(p)>V(n)$ the individual becomes a professional worker. Denote by $w_{p}^{*}$ the wage paid professional workers making them indifferent between becoming a professional and a nonprofessional. From (4) we compute $w_{p}^{*}$,

$$
w_{p}^{*}=\frac{\left(w_{n}+q(n) U(n)\right)(r+q(p))}{r+q(n)}-(s+q(p) U(p)) .
$$

If wages in the professional occupation are less than $w_{p}^{*}$, this individual will decide not to obtain professional qualifications. On the other hand, if the wages the professional worker earns are at least $w_{p}^{*}$, then this individual will decide to become a professional worker.

Now let us consider how $w_{p}^{*}$ changes as parameters change:

Increasing the reputation and status (s) that a professional obtains from his profession decreases the wage that makes the individual indifferent between occupations. Thus as the status (s) of professionals increase, more individuals become professionals, $\frac{\partial w_{p}^{*}}{\partial s}<0$.

What this says that as the status a worker receives from becoming a professional increases, the wage that will make him indifferent between being and not being a professional decreases, thus increasing the number choosing a professional occupation and the extra schooling this choice entails.

If individual preferences for the present $(r)$ increase, we have $\frac{\partial w_{p}^{*}}{\partial r}=\left(w_{n}+q(n) U(n)\right) \frac{(q(n)-q(p))}{(r+q(n))^{2}}$. The sign of this expression depends on the difference between the probabilities of emigration for the two occupations.

If the probability of a professional worker emigrating is lower than the probability of a nonprofessional worker emigrating, $(q(n)-q(p))>0$, then increased preference for the present increases the wage that makes the individual indifferent. Fewer people stay in school studying for the professional degree. 
The main idea is that as time preference increases, the weight on the future decreases and people care more about the present. Thus if the probability of migrating for a professional worker is lower than for a non-professional worker, the wages needed for a worker $i$ to choose the professional occupation increase and the wage has to go up to make him want to migrate.

\section{EMIGRATION OPTIONS, $w_{p}^{*}$, AND CHOICE OF PROFESSION}

Let us now consider how different emigration possibilities affect $w_{p}^{*}$. As the expected lifetime utility of professional workers who emigrate, $U(p)$, increases, the wage that makes the individual indifferent decreases, $\frac{\partial w_{p}^{*}}{\partial U(p)}<0$, as he can gain more by emigrating. And as the expected lifetime utility of non-professional workers who emigrate, $U(n)$, increases, the wage that makes the individual indifferent increases, $\frac{\partial w_{p}^{*}}{\partial U(n)}>0$, since the opportunity cost has increased. This is a comparative static calculation. The effect of a change in the migrant's utility on $w_{p}^{*}$ depends on the utility the migrant obtains after migration.

If a professional worker obtains a high utility after migration, then he will be willing to become a professional at a lower wage (lower $\left.w_{p}^{*}\right)$; however, if there are more benefits for a nonprofessional worker in the host country, then the worker needs a higher wage to become a professional.

Thus, it all depends on the opportunities the worker may have in the home and host countries. For locations that individuals can migrate to that have more opportunities for professional workers (relative to nonprofessional workers) the value of $w_{p}^{*}$ decreases, while for locations that a nonprofessional worker has more opportunities (relative to a professional worker) the value of $w_{p}^{*} \quad$ increases. In other words, one can think of it as an option to migrate to different places with different expected income.

Note that if $w_{p}>w_{p}^{*}$ then individuals will choose a professional occupation. With probability $q(p)$ the individual after becoming a professional worker will emigrate. With probability $1-q(p)$, the individual will not emigrate and will stay at in the home country. If earnings in the host country are such that this wage is sufficiently large, then individuals are choosing a professional occupation in order to emigrate and earn high wages in the host country. However, only a proportion $q(p)$ actually emigrate while a proportion $1-q(p)$ do not emigrate. In the literature this is called a brain gain since some individuals who decided to become professionals in order to emigrate in the end stay in their home country adding to its human capital. Hence, the home country benefits from the possibility of emigration. 


\section{INTRODUCING RETURN MIGRATION INTO THE MODEL}

To better understand the results, consider the extreme case where the probability of migrating is low for the professional worker while it is higher for the non-professional worker. For emphasis, and only for emphasis reasons, assume that professionals have a zero probability of emigrating $q(p)=0$. Changing this to a positive probability will not change the main results presented below.

Explicitly write the lifetime utility of a migrant taking into consideration the probability of return migration. With probability $k(n)$ a non-professional migrant will return home. This can happen, for example, as a result of being illegal, apprehended and deported, $q_{1}$, or the immigrant simply decides to return home with probability $q_{2}$. An immigrant's utility is independent of the identity of his or her previous employer. Hence,

$$
r U(n)=w_{f}-k(U(n)-V(n)),
$$

where, $\mathrm{w}_{f}$ is the immigrant's income in the host country, $U(n)$ is the expected utility of an employed non-professional worker who migrated, and $V(n)$ is that worker's expected lifetime utility.

From (6) we obtain that

$$
U(n)=\frac{w_{f}+V(n)}{k+r}
$$

Rewrite the lifetime utility of an individual taking into consideration components determining the lifetime utility of an immigrant. Substituting (7) into (4), we obtain

$$
V(n)=\frac{w_{n}+q(n)\left(\frac{w_{f}+V(n)}{k+r}\right)}{r+q(n)} .
$$

Thus,

$$
V(n)=\frac{w_{n}(k+r)+q(n) w_{f}}{(r+q(n))(k+r)-q(n)}
$$

Let us use this to update the wage that makes the individual indifferent between choosing to be a professional and a nonprofessional worker. Comparing (9) with $V(p)=\frac{w_{p}+s}{r}$ (the expected discounted utility of a professional worker with a probability of migrating equaling zero, $q(p)=0)$, we see that the wage of a professional worker that will make the individual indifferent between becoming a professional worker or a non-professional worker will satisfy $V(p)=V(n)$. If $V(p)<V(n)$ then the individual becomes a non-professional worker; if $V(p)>V(n)$ the individual becomes a professional worker. Denote by $w_{p}^{* *}$ the wage that a professional worker 
must earn to make him indifferent between becoming a professional worker and a nonprofessional worker. From (4) we compute $w_{p}^{* *}$,

$$
\frac{w_{p}^{* *}+s}{r}=\frac{w_{n}(k+r)+q(n) w_{f}}{(r+q(n))(k+r)-q(n)} .
$$

Thus, when accounting for the possibility of return migration, the wage that a professional has to earn in the host country to make an individual indifferent between this occupation and being a non-professional, must satisfy

$$
w_{p}^{* *}=r \frac{w_{n}(k+r)+q(p) w_{f}}{(r+q(n))(k+r)-q(n)}-s .
$$

This wage determines whether an individual will be a professional or non-professional worker. Consider how it changes with changes in the parameters.

Increasing the reputation and status (s) a professional worker obtains from his profession will decrease the wage that makes the individual indifferent between the professions.

Thus as status, $s$, increases more individuals will stay in school and become professional workers, $\frac{\partial w_{p}^{* *}}{\partial s}<0$.

As the income of a non-professional worker in the home country or host country increases, $w_{n}$ or $w_{f}$, the wage that makes the individual indifferent between the two options increases $\frac{\partial w_{p}^{* *}}{\partial w_{n}}>0$ and $\frac{\partial w_{p}^{* *}}{\partial w_{f}}>0$

Since $r+k \leq 2$ and $w_{f} \geq w_{n}$ we obtain,

As the probability of migration increases, $q(n)$, the wage that makes the individual indifferent, $w_{p}^{* *}$ will increase: $\frac{\partial w_{p}^{* *}}{\partial q(n)}=r \frac{\left(w_{f}+w_{n}-w_{n}(k+r)\right)}{((r+q(n))(k+r)-q(n))^{2}}>0$.

Thus if wages in the host country are higher than those in the home country, $w_{f} \geq w_{n}$, then increasing the probability of migration will increase the chances an individual will choose a nonprofessional occupation.

As presented above, the status and reputation obtained from a professional job play an important role in determining the outcome. However, this is not sufficient. The wage and the probability of finding a job in the profession and moreover, the probability of migration are key factors in determining the individual's choice. Thus we may well find those that without migration possibilities would choose a professional occupation. However, including the possibility of migration decreases the probability of choosing a professional occupation. 


\section{EVIDENCE}

The story we have just told examines the brain drain as a consequence of a component of the brain gain story. Very large host-home income difference encourages those who finish compulsory schooling not to continue their studies - to forsake further schooling because of opportunities to migrate to high paying low-skilled jobs. Our modeling allows us to establish the circumstances under which this type of forsaken schooling will occur and the trade-offs that policymakers need to consider (Epstein, 2013; Epstein and Gang, 2010).

There is a series of papers empirically showing that this phenomenon is not a purely theoretical construct but is a worrisome occurrence. Our work has centered on Central Asia, particularly Tajikistan but also Uzbekistan and Kyrgyzstan. These three former Soviet Republics are major migrant-sending countries to Russia. The labor migration is a relatively new phenomenon in these former Soviet countries. The existing large income differences between Russia and these Central Asian countries along with no-visa free entry to Russia attract the economically active populations of these countries to Russia.

Abdulloev, Epstein, and Gang (2020) estimate several models of decisions over professional education and labor migration in three Central Asian republics, Kyrgyzstan, Tajikistan and Uzbekistan in 2013. They looked at whether an individual after completing compulsory schooling decides to forego professional schooling and migrate abroad for higher earnings. They estimated five regression models: (i) a probit regression of impact of migration experience on the tertiary education decision; (ii) a probit regression of professional education on the migration decision; (iii) an ordered probit regression of impact of migration experience on different education levels; (iv) the instrumented variable Bivariate Probit model; (v) the instrumental variable regression based on two-stage least square estimation. In all our estimated regression models the impact of labor migration on the forsaken professional schooling was significant. Such empirical analysis suggests that these Central Asian migrant - sending countries face a loss in human capital formation because of the opportunity to earn abroad by working in higher paid low-skill occupations.

In another paper, they took a closer look at the forsaken schooling phenomenon in migration in Tajikistan, which was the most remittance dependent country in 2013 (Abdulloev, Epstein, and Gang, 2021). They found that the forsaken schooling phenomenon in migration in Tajikistan is increasing until 2011 as more and more people without professional education choose to migrate, while people with professional education remained in their home country. Despite the fact that Tajikistan has good overall school enrollment rates, young men are discouraged in finding jobs after completing school, and therefore choose to not go for higher studies; instead they migrate abroad (Abdulloev, 2018). Such results suggest that people in Tajikistan choose to forgo the professional education in favor of migration.

Another paper looked at how the forsaken schooling phenomenon in Tajikistan changed because of Russia's recent tightened migration policy and economic slowdown, and policies promoting fair access to professional education in Tajikistan (Abdulloev, 2020). Russia faced a financial crisis in 2014-2017, when its currency significantly devaluated because of a large capital outflow from Russia. During this crisis, Russia introduced stricter migration policies, including reentry bans for migrants who have administrative violations and fines, using biometric passports for entry to the country, and a new work permission patent system with compulsory tests. These policies and the economic slowdown decreased labor emigration from Tajikistan. In addition, Tajikistan implemented a large educational reform establishing a centralized entry examination system, hich provides fair and equal access to professional education in Tajikistan. Under this new examination system, the enrollment of young people into vocational and tertiary schools 
increased in Tajikistan. All these weakened the forsaken schooling phenomenon in Tajikistan after 2014.

\section{CONCLUSION}

Potential migrant's education decisions are limited by their local or even national job market, but may reflect the job opportunities abroad. We offer a possible explanation for these results in a theoretical model. Our theory explains the forsaken schooling phenomenon as a result of lowand high-skilled and skilled workers accepting relatively high-wage positions in host countries, which leads to the forgoing of professional schooling in the home country. Important here is the status gains one receives by obtaining the education necessary to hold a professional job in contrast to a non-professional job.

Our theory explains the forsaken schooling phenomenon as a result of low-skilled and skilled workers accepting low-skilled positions in host countries, which leads to the forgoing of professional schooling in the home country. Over time we expect, therefore, people who decide to migrate abroad will have either lower years of schooling, or generally have not completed professional schools (technical-vocational or tertiary).

We point to three current works on several Central Asian countries. Because of large and persistent income differentials and encouraged by lax barriers, many workers from Tajikistan, Uzbekistan and Kyrgyzstan migrate to Russia. These papers point to a negative impact on professional schooling - a fall in human capital creation. Looking specifically at Tajikistan, this pattern changes over time - increasing until 2013 as high status positions seem to hold back those with professional education while others migrate. Eventually, those completing their compulsory schooling do not continue. Rather, they emigrate. However, after 2014, in response to stricter Russian immigration policies and equalizing educational reform in Tajikistan, the forsaken schooling phenomenon weakened.

Our theme is that there can be a downside to the brain gain story. This is an important topic for education and labor policy formulation. Underinvestment in education may have short run benefits to households, but, in the long run, economic growth and development can be negatively impacted by the lack of skill in society. Our theory shows that the relationship between migration and professional education may generate a loss in human capital formation. 


\section{REFERENCES}

Abdulloev, I. (2018). Job dissatisfaction and migration: evidence from Tajikistan. IZA Journal of Development and Migration, 8 (21). https://doi.org/10.1186/s40176-018-0132-8

Abdulloev, I. (2020) Changes in the Forsaken Schooling and Migration Relationship in Tajikistan, IZA Discussion Paper Series No. 13435. http://ftp.iza.org/dp13435.pdf forthcoming in Brain Drain vs Brain Circulation (Central Asia), Nova Science Publishers.

Abdulloev, I., Epstein, G. S., \& Gang, I. N. (2020). Migration and Forsaken Schooling in Kyrgyzstan, Tajikistan, and Uzbekistan, IZA Journal of Development and Migration, 11(1), 20200004. doi: https://doi.org/10.2478/izajodm-2020-0004

Abdulloev, I., Epstein, G. S., \& Gang, I. N. (2021). Schooling Forsaken: Education and Migration in R.M. Sauer, World Scientific Encyclopedia of Global Migration, World Scientific Publishing, forthcoming. Currently available as a GLO discussion paper: https://www.econstor.eu/bitstream/10419/223228/1/GLO-DP-0641.pdf

Abdulloev, I., Gang, I. N., \& Landon-Lane, J. (2012). Migration as a substitute for informal activities: evidence from Tajikistan. Emerald Group Publishing Limited. Polachek, S. W., \& Tatsiramos, K. (Eds.). (2012). Informal Employment in Emerging and Transition Economies. Emerald Group Publishing. https://doi.org/10.1108/S0147$\underline{9121(2012) 0000034009}$

Acosta, P. (2006). Labor supply, school attendance, and remittances from international migration: the case of El Salvador. World Bank Policy Research Working Paper, 3903, World Bank.

Amuedo-Dorantes, C., \& Pozo, S. (2010). Accounting for remittance and migration effects on children's schooling. World Development, 38(12), 1747-1759.

Antman, F. M. (2012). Gender, educational attainment, and the impact of parental migration on children left behind. Journal of Population Economics, 25(4), 1187-1214.

Beine, M., Docquier, F., \& Rapoport, H. (2008). Brain drain and human capital formation in developing countries: Winners and losers. The Economic Journal, 118(528), 631-652.

Beine, M., Docquier, F., \& Rapoport, H. (2001). Brain drain and economic growth: theory and evidence. Journal of Development Economics, 64(1), 275-289.

Bhagwati, J., \& Hamada, K. (1974). The brain drain, international integration of markets for professionals and unemployment: a theoretical analysis. Journal of Development Economics, 1(1), 19-42.

Bredtmann, J., Martínez Flores, F., \& Otten, S. (2019). Remittances and the brain drain: Evidence from microdata for Sub-Saharan Africa. The Journal of Development Studies, 55(7), 1455-1476.

Calero, C., Bedi, A. S., \& Sparrow, R. (2009). Remittances, liquidity constraints and human capital investments in Ecuador. World Development, 37(6), 1143-1154.

Co, C.Y., Gang, I. N., \& Yun, M. S. (2000). Returns to returning. Journal of Population Economics, 13(1), 57-79. https://doi.org/10.1007/s001480050123 
Dai, T., Liu, X., \& Xie, B. (2015). Brain drain reversal and return subsidy. Journal of Comparative Economics, 43(2), 443-455.

Dimova, R. (2017). Migrant Remittances and Beyond: The development implications of human capital mobility and accompanying financial tools in G. Giorgioni (ed), Development Finance, Palgrave Studies in Impact Finance, 111-145.

Dimova, R., Epstein, G. S., \& Gang, I. N. (2015). Migration, Transfers and Child Labor. Review of Development Economics, 19(3), 735-747.

Duryea, S., Cox, A., \& Ureta, M. (2003). Adolescents and human capital formation. In Duryea, S., Cox, A., \& Ureta, M. (eds), Critical decisions at a critical age: Adolescents and young adults in Latin America, Inter-American Development Bank, 1-23.

Edwards, A. C., \& Ureta, M. (2003). International migration, remittances, and schooling: evidence from El Salvador. Journal of Development Economics, 72(2), 429-461.

Elsheniti, O. (2014). Intergenerational mobility, income inequality and children's human capital investment. PhD Dissertation, Rutgers University, New Brunswick, NJ.

Epstein, G. S. (2008) "Herd and Network Effects in Migration Decision-Making", Journal of Ethnic and Migration Studies, 34(4), $567-583$.

Epstein, G. S. (2013). Frontier issues on the political economy of migration in A. Constant and K. F. Zimmermann (eds.) International Handbook on the Economics of Migration (pp. 411-431) Cheltenham, UK: Edward Plgar https://doi.org/10.4337/9781782546078.00032

Epstein G.S. \& Kahana, N. (2008). Child Labor and Temporary Emigration. Economics Letters 99(3) (pp. 545-548).

Epstein, G. S. \& Gang, I. N. (2010). A political economy of the immigrant assimilation: internal dynamics in G. S. Epstein, and I. N. Gang, (eds.), Migration and Culture: Frontiers of Economics and Globalization, volume 8, Emerald Group Publishing Limited. https://doi.org/10.1108/S1574-8715(2010)0000008019

Epstein, G. S., \& Hillman, A. L. (2003). Unemployed immigrants and voter sentiment in the welfare state. Journal of Public Economics, 87(7), 1641-1655. https://doi.org/10.1016/S0047-2727(01)00197-9

Faini, R. (2003). The Brain Drain: an Unmitigated Blessing? (No. 173). Centro Studi Luca d'Agliano, University of Milano. https://dx.doi.org/10.2139/ssrn.463021

Faini, R. (2007). Remittances \& the Brain Drain: Do more skilled migrants remit more?. The World Bank Economic Review, 21(2), 177-191. https://doi.org/10.1093/wber/lhm006 also, IZA Discussion paper 2177 (2006).

Fields, G. S. (1974). The private demand for education in relation to labour market conditions in less-developed countries. The Economic Journal, 84(336), 906-925.

Grubel, H. B., \& Scott, A. D. (1966). The international flow of human capital. The American Economic Review, 56(1/2), 268-274.

Mountford, A. (1997). Can a brain drain be good for growth in the source economy?. Journal of Development Economics, 53(2), 287-303. 
Özden, Ç. G. (2006). Educated migrants: is there a brain waste? In Ç. G. Özden, M. Schiff (Eds.), International migration, remittances, and the brain drain (pp. 227-244). Washington, DC: World Bank.

Piracha, M., Randazzo, T., \& Vadean, F. (2013). Remittances and occupational outcomes of the household members left-behind. IZA Discussion Paper No. 7582. Available at SSRN: http://ssrn.com/abstract $=2322087$

Stark, O., \& Wang, Y. (2002). Inducing human capital formation: migration as a substitute for subsidies. Journal of Public Economics, 86(1), 29-46.

Stark, O., \& Byra, L. (2012). A back-door brain drain. Economics Letters, 116(3), 273-276.

Stark, O., Helmenstein, C., \& Prskawetz, A. (1997). A brain gain with a brain drain. Economics Letters, 55(2), 227-234.

Stark, O., Helmenstein, C., \& Prskawetz, A. (1998). Human capital depletion, human capital formation, and migration: a blessing or a "curse"?. Economics Letters, 60(3), 363-367.

Weiss, Y., Sauer, R. M., \& Gotlibovski, M. (2003). Immigration, search, and loss of skill. Journal of Labor Economics, 21(3), 557-591.

Yang, D. (2005). International migration, human capital, and entrepreneurship: Evidence from Philippine migrants' exchange rate shocks. World Bank Policy Research Working Paper 3578. The World Bank. 